\title{
FEASIBILITY STUDY ON BAGASSE ASH STABILIZED MUD BLOCKS WITH CEMENT AS PRIMARY STABILIZER
}

\author{
Chethan B A ${ }^{1}$, Amar $R^{2}$, Hema $\mathbf{N}^{3}$ \\ ${ }^{1}$ Assistant Professor, Civil Engineering Department, Government Engineering College Hassan, Karnataka, India \\ ${ }^{2}$ Assistant Professor, Civil Engineering Department, Government Engineering College Hassan, Karnataka, India \\ ${ }^{3}$ PG Student, Civil Engineering Department, Government Engineering College Hassan, Karnataka, India
}

\begin{abstract}
Due to quick urbanization, there is an immense interest for good quality building units. There is a degradation of environment due to generation of large amount of waste from different industries. Using this waste in constructive applications is a suitable alternative. Stabilized Mud Block (SMB) is an economical, energy efficient and eco friendly option for ordinary building block like Concrete block and burnt clay brick. Bagasse ash from Sugar factory, quarry dust and regionally available soil are used in the production of $S M B$.

Sand content of the soil is increased by using quarry dust which alters the soil to make it suitable for block production.8\% of cement by weight of soil is fixed as stabilizer by studying the literatures. Diverse mixes of stabilizers are used by substituting every percentage of cement by bagasse ash and replacing soil with ash. Tests on blocks such as density, compressive strength, water absorption, efflorescence, dimensionality, durability test and prism tests are conducted to access their fundamental properties and performance. The outcomes demonstrated that compressive strength and block density is diminished with each percentage substitution of cement by bagasse ash. Water absorption values are well within permissible limits. A stabilizer mix $4 \%$ cement+ 4\%Baggase ash has fulfilled the necessities of Class 30 evaluation of SMB as given in IS: 1725-1982. Bagasse ash can be utilized as a supplementary stabilizer with cement in the production of SMB. Use of industrial waste and bagasse ash in SMB have numerous advantages like cost reduction and viable management of waste by reducing environmental impacts.
\end{abstract}

Keywords: Bagasse ash, stabilizer, mechanical and durability tests, economical and ecofriendly $* * *$

\section{INTRODUCTION}

Infrastructural development of a country mainly depends upon growth of construction industry. From last few decades construction industry is growing rapidly. Hence there is a need to focus on the production of low cost building units. Now a days, variety of building blocks such as concrete blocks, burnt clay bricks, aerated blocks, size stone etc and building techniques such as brick masonry construction, $\mathrm{RCC}$ framed construction etc are present in construction industry. But some of these are not cost effective and are responsible for high carbon emission. Hence it is need to give importance to the production of cost effective and environmental friendly alternative building blocks. FAL-G bricks stabilized mud blocks and fly ash bricks are some of the alternative building blocks which results in low carbon emission.

In most areas of the world, soil is used as valuable material for mud construction. Mud construction is the oldest form of construction. In developing countries, the most energy efficient and economical form of construction is mud construction. But this form of construction is subjected to various environmental conditions. So there is essential to boost mechanical and durability properties of the soil. Such properties can be improved by adding certain percentage of stabilizing agent such as cement, lime, natural and industrial byproducts .The main objective of soil stabilization is to alter the soil properties so that it will give the desired stability. Compaction reduces permeability and increases strength and density of the block.

For masonry wall construction, stabilized mud block is emerged as cost effective, ecofriendly, energy efficient and low emboided energy building block.

\subsection{Significance}

There is a necessity to conduct experimental study to improve the bearing capacity of the soil and to improve the mechanical and durability properties of the blocks .By doing so, it is possible to ensure low cost alternative for construction, thereby reducing the environmental impacts and reducing the exploitation of non renewable resources and dependence on scarcely available materials.

\subsection{Objective}

- To identify the regionally accessible soil and to find its properties for the suitability in production of SMB.

- $\quad$ Production of SMB with Soil $(77 \%)+$ Cement $(0-8 \%)+$ Quarry Dust $(15 \%)+\mathrm{BA}(0-8 \%)$, for cement replaced with BA.

- To conduct various mechanical and durability tests on blocks made with above mentioned combinations. 


\subsection{Quarry Industry Waste}

Crushing process done to obtain aggregates from stone will generate a waste called quarry dust. Quarry Rock Dust Crushed sand under $4.75 \mathrm{~mm}$ is delivered from hard stone rock utilizing condition of crushing plants. Generation of quarry fines is an outcome of extraction and handling in a quarry .The quantity generated relies upon the stone sort, measure of separation by impacting and kind of smashing utilized.

It has properties and chemical composition similar to that of sand. It is grey in colour. The positive point of utilizing quarry dust are financially viable, effortlessly accessible and the utilization diminishes the contamination in environment.

\subsection{Sugar Cane Bagasse Ash}

India is the second largest sugar producing country in the world. It contributes about $15 \%$ of the global production. After extracting the juice from sugarcane, a residue is left which is bagasse. This bagasse is used as fuel to run boilers in factory. Burning of bagasse at $700^{\circ} \mathrm{C}$ will result in the generation of solid waste known as Bagasse Ash. Because of its non biodegradable nature, it is considered as waste. It causes contamination of air, water, land and also threat to human health causing lung diseases. So scientific method of disposal of this waste is necessary.

In construction industry, it is used for various purposes such as stabilization of soil for construction of roads and embankments, stabilized mud blocks etc. It possesses pozzolonic property because of presence of high silica content. It is used as supplementary material in concrete and also used in manufacture of biocement and has yielded positive result. Hence there is need to carry out research on the properties of baggase fiery debris stabilized mud blocks, to produce environmental friendly, economical and easily available blocks.

Table 1: Chemical composition of bagasse ash

\begin{tabular}{|l|l|}
\hline Constituents & \% by mass \\
\hline $\mathrm{SiO}_{2}$ & 68.12 \\
\hline $\mathrm{Al}_{2} \mathrm{O}_{3}$ & 1.834 \\
\hline $\mathrm{CaO}$ & 5.993 \\
\hline $\mathrm{Fe}_{2} \mathrm{O}_{3}$ & 2.10 \\
\hline $\mathrm{K}_{2} \mathrm{O}$ & 8.645 \\
\hline $\mathrm{MgO}$ & 2.995 \\
\hline $\mathrm{SO}_{3}$ & 2.450 \\
\hline
\end{tabular}

\subsection{Literature Review}

Ajay Gupta et al [1] have conveyed a test examination on describing the properties of balanced out mud squares masonry utilizing cement soil mortars and exhibited the results. Results are: 1) Block quality influences the masonry strength, increase in masonry strength is directly proportional to increase in block strength 2)Cement soil mortars impacts the quality of SMB masonry and the quality is touchy to cement proportion of the mortar and is less delicate to earth substance of the mortar blend. Masonry utilizing cement mortar and cement lime mortar shows lower modulus than the SMB masonry utilizing cement soil mortar

Apurva Kulkarni et al [2] have attempted to replace bagasse ash in flyash bricks. They have focused on utilization of industrial waste bagasse ash for economical, environmental and technical reasons. $0 \%-60 \%$ of flyash is replaced with bagasse ash and $0 \%, 5 \%, 10 \% 15 \%$ and $20 \%$ of lime is replaced with bagasse ash. For $10 \%$ replacement of flyash and lime with baggase ash ,maximum compressive strength is obtained at this replacement. The study reveals the fact that the seismic weight of building is reduced by use of baggase ash bricks

Ram W. Salim [9] he carried out the experimental investigation on stabilized mud blocks manufactured by supplementing $3 \%$ to $10 \%$ of bagasse ash in the interval of $3 \%$.Unstabilized blocks did not satisfy the requirements of code for 28days test results. But the stabilized compressed earth blocks satisfy the requirement of code for minimum compressive strength. Compressive quality development rate between 14-21 day is higher for addition of $10 \%$ ash, where as 21-28 day compressive higher for 3\%, 5\% and $8 \%$ of ash. The results shows that there is disintergration of unstabilized mud blocks into smaller fragments, where as concrete mode of failure pattern is observed in stabilized mud blocks.

\section{MATERIALS AND MIX PROPORTION}

Materials used are Soil, quarry dust,cement, bagasse ash, water

\subsection{Soil}

Generally accessible soil in the premises of campus is utilized to carry out present work.

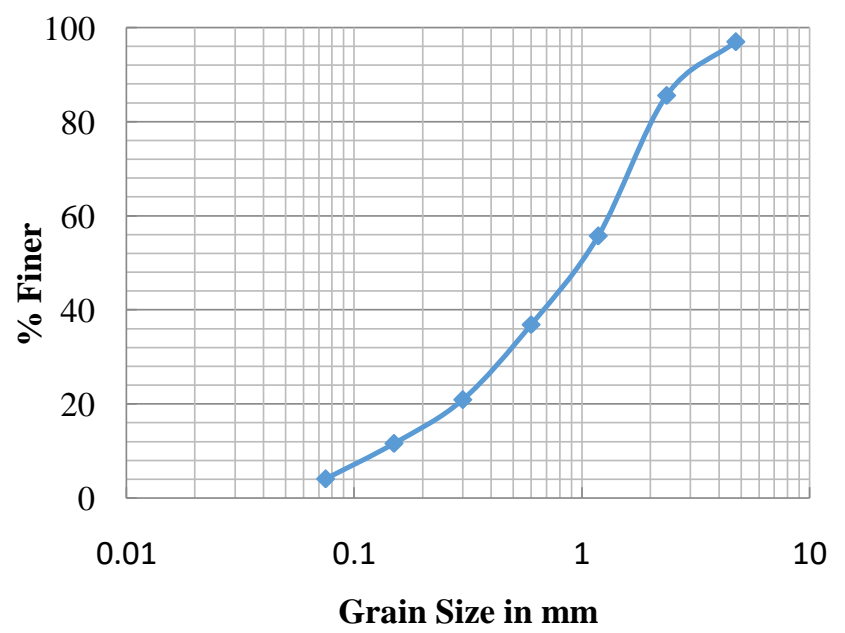

Fig 1: Soil Particle Size Distribution Curve

Soil is having a good representation of all sizes of particles, therefore it can be classified as well graded sandy soil. 


\subsection{Quarry Dust}

Quarry dust available from near by industry is used to increase the sand content of the soil because it contains sand less than $60 \%$.

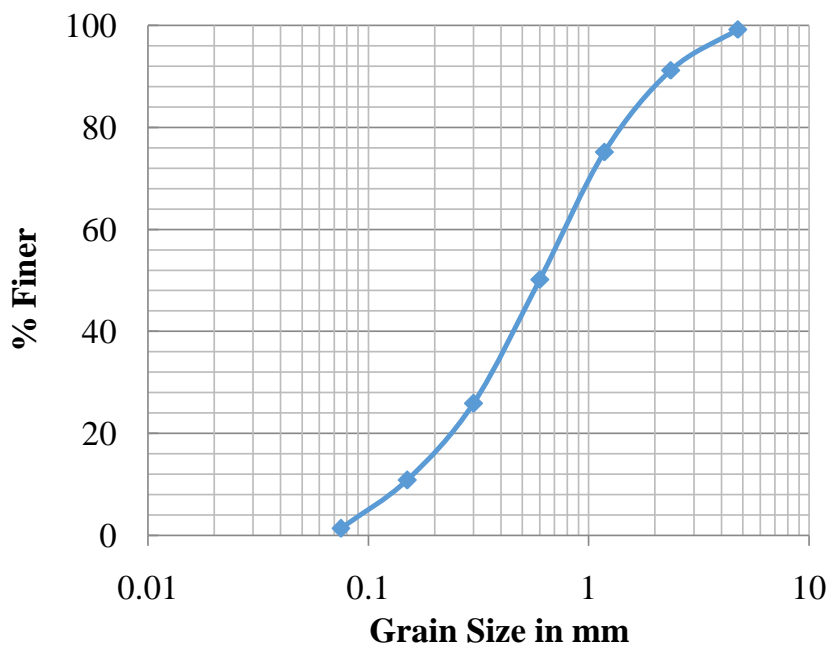

Fig 2: Particle Size Distribution Curve

It belongs to Zone -2 , according to IS:383-1970

\subsection{Cement}

Ordinary Portland cement of 53 grade is used

\subsection{Baggasse Ash}

Baggasse ash is obtained from sugar factory located in Srinivaspura village, $6 \mathrm{~km}$ away from Channarayapatna taluk of Hassan district.

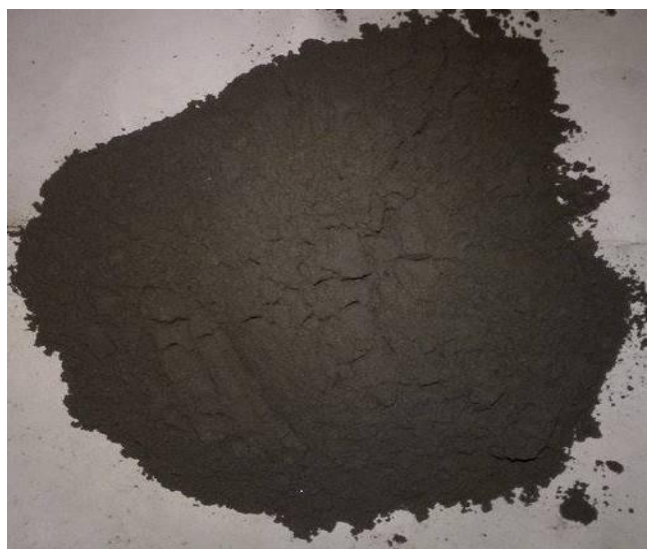

Fig 3: Bagasse Ash

Table 2: Physical Properties

\begin{tabular}{|l|l|l|}
\hline Sl.No. & Physical Properties \\
\hline $\mathbf{1}$ & Colour & Light Blackish \\
\hline $\mathbf{2}$ & Particle size & Less than $90 \mu$ \\
\hline $\mathbf{3}$ & Specific gravity & 1.97 \\
\hline $\mathbf{4}$ & Consistency & $38 \%$ \\
\hline $\mathbf{5}$ & $\begin{array}{l}\text { Initial Setting } \\
\text { Time }\end{array}$ & 210 minute \\
\hline $\mathbf{6}$ & Final Setting Time & 320 minute \\
\hline
\end{tabular}

The tests are carried out as per the procedure mentioned in IS: 1727 -1967 for Pozzolanic Materials.

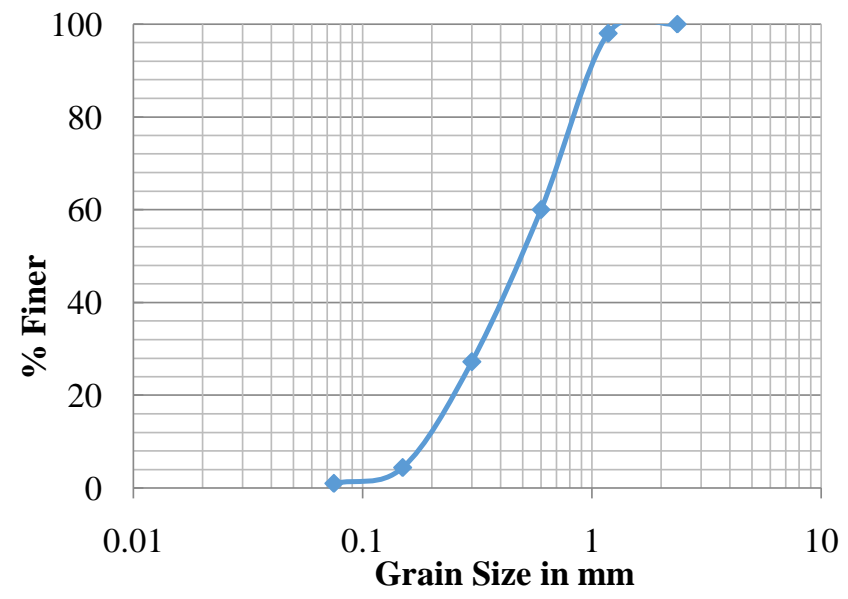

Fig 4: Bagasse Ash Particle Size Distribution Curve

It belongs to Zone -3 , according to IS:383-1970

Since particles of sizes greater than $1.18 \mathrm{~mm}$ are missing (from graph), the bagasse ash can be classified as material of uniformly graded fine particles.

\subsection{Mix Proportion}

For the production of SMB from the soil which is non expansive, the amount of stabilizer required is about $7 \%$ to $10 \% .8 \%$ cement is used to block stabilization in the present work and every percentage of cement is substituted by bagasse ash. Soil and quarry dust quantity is kept constant. Production of blocks relies on impressive degree of its thickness, for this compaction of earth is done with optimum water percentage. When all said is done $10-12 \%$ of water by weight of dry materials is generally added. By experimentation strategy $10 \%$ water content was discovered to be agreeable.

For SMB production, a basic dry density of $1.85 \mathrm{~g} / \mathrm{cm}^{3}$ is essential. A mould of $230 * 108 * 100$ needs 4964 grams of dry materials in the wake of wastage of materials of about $8 \%$.

Table 3: Mix Proportion for block

\begin{tabular}{|l|}
\hline $\begin{array}{l}\text { Combination } \\
\text { of stabilizer }\end{array}$ \\
\hline C8B0 \\
\hline C7B1 \\
\hline C6B2 \\
\hline C5B3 \\
\hline C4B4 \\
\hline C3B5 \\
\hline C2B6 \\
\hline C1B7 \\
\hline C0B8 \\
\hline SMB(ref)C4 \\
\hline
\end{tabular}

C8B0- Cement $8 \%+0 \%$ Bagasse ash

SMB(ref) C4 - made with only $4 \%$ of cement 


\section{EXPERIMENTAL METHODOLOGY AND}

\section{RESULTS}

\subsection{Block Density Test}

From the samples random selection of blocks is done .Weight of blocks and dimensions are noted.

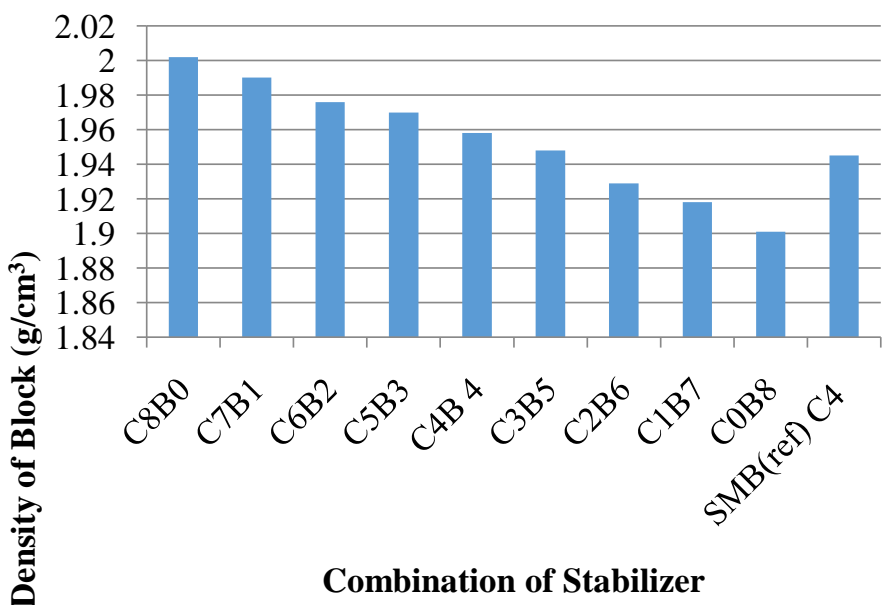

Fig 5: Block density for varying $\%$ of cement and baggase ash

Because of declination in the content of cement, declination is noticed in density. A distinction of $5.31 \%$ is seen in density of blocks with $\mathrm{C} 8 \mathrm{~B} 0$ and $\mathrm{C} 0 \mathrm{~B} 8$ combination. All density values are well over the base allowable estimation value. Little increment of $1 \%$ in density is noticed for C4 B4 block when contrasted with $\mathrm{C} 4$ block.

\subsection{Compressive Strength}

The load that causes failure is noted down and is the maximum load. For saturated test, the process is similar but the blocks are submerged in water for 24 hours

Table 4: Compressive strength for 28 days

\begin{tabular}{|l|l|l|}
\hline $\begin{array}{l}\text { Combination of } \\
\text { stabilizer }\end{array}$ & DCS & WCS \\
\hline C8B0 & 8.822 & 5.323 \\
\hline C7B1 & 8.442 & 5.052 \\
\hline C6B2 & 7.980 & 4.702 \\
\hline C5B3 & 6.305 & 4.00 \\
\hline C4B4 & 6.152 & 3.703 \\
\hline C3B5 & 4.230 & 2.632 \\
\hline C2B6 & 3.323 & 2.029 \\
\hline C1B7 & 2.650 & - \\
\hline C0B8 & 2.353 & - \\
\hline SMB(ref)C4 & 5.348 & 3.183 \\
\hline
\end{tabular}

DCS - Dry compressive strength

WCS - Wet compressive strength

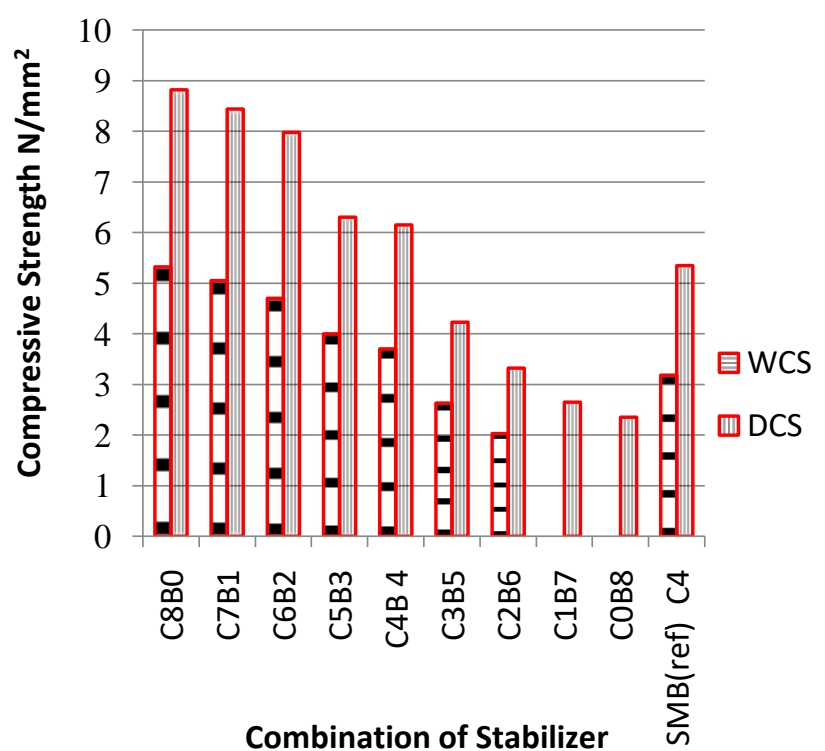

Fig 6: WCS and DCS for 28 Days

28 days WCS is around $60 \%$ of DCS . Increment of $16 \%$ and $14.8 \%$ is seen in WCS and DCS separately for 28 days curing, for block C4B4 in contrast with SMB(ref)C4. There is no wet compressive strength for the blocks $\mathrm{C} 1 \mathrm{~B} 7$ and C0B8. Blocks with below $2 \%$ cement substance deteriorated after submersion.

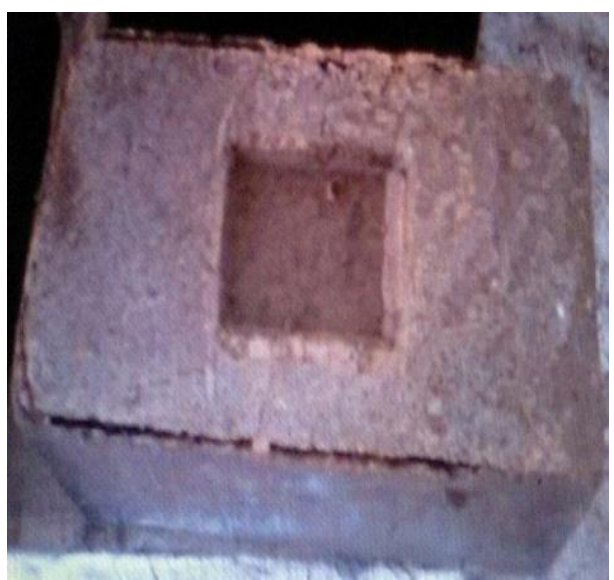

Fig 7: Failure Pattern of Blocks

Brick work fails by pounding, breaking into segments or by creating vertical splits. The bagasse ash blocks have failed by creating vertical breaks. After breakage also the blocks held their shape.

\subsection{Water Absorption of Blocks}

The blocks are dried in an oven till it achieves constant mass. Immersion of dried blocks completely in a clean water for 24 hours is done. After this immersion period, the blocks surface is dried and weight is noted down. 


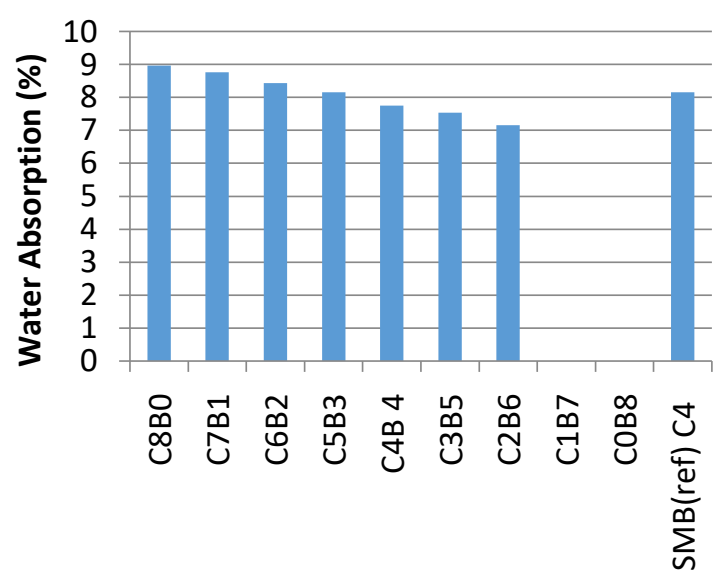

Combination of Stabilizer

Fig 8: Water Absorption of Blocks

Water absorption values ranges from $7.156 \%$ to $8.96 \%$ and the qualities were discovered to be progressively diminishing with inclination in bagasse ash content. According to IS 1725-1982 SMB having a place with Clause 30 evaluation should have water assimilation values under $15 \%$. Water engrossing property of blocks will satisfy the requirements of codal procurements.C1B7 and $\mathrm{C} 0 \mathrm{~B} 8$ blend mix blocks get deteriorated after drowning in water. The deterioration of blocks may be because of deficient binding substance.

\subsection{Efflorescence on Blocks}

A shallow level base dish containing adequate refined water to totally immerse the sample is utilized for the test. Place the end of the blocks in the dish, the depth of water in dish being $25 \mathrm{~mm}$. Allow the blocks for complete ingestion of water. The point when the water has been retained and block gives off an impression of being dry, put a comparative amount of water in the dish for second time and permit it to dissipate as some time recently. Inspect the blocks for efflorescence after the second dissipation and report the outcomes

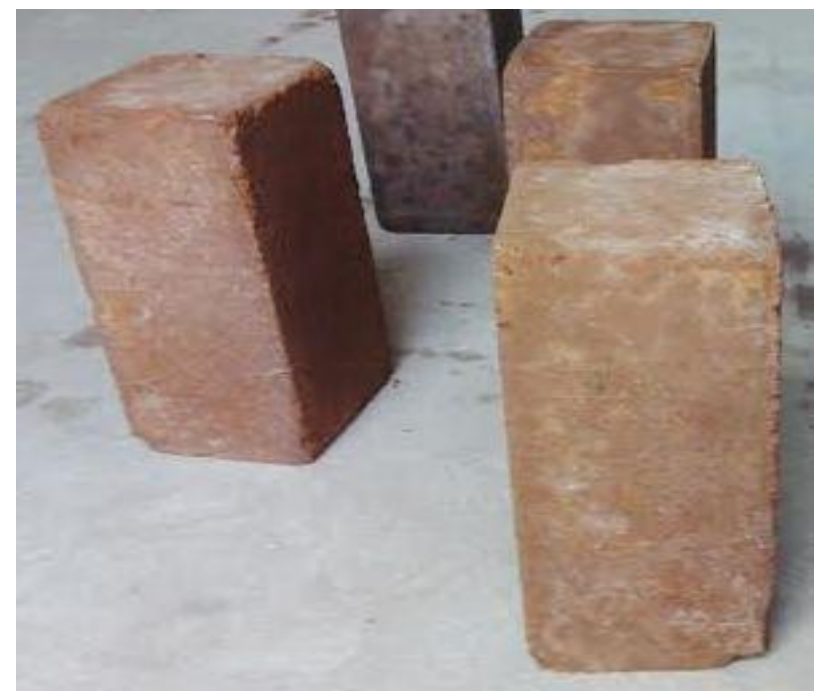

Fig 9: Efflorescence on Blocks
As the area secured by blooming on the square ranges from $10 \%$ to $30 \%$ of aggregate region, the degree of blossoming is accounted for as moderate.

\subsection{Alternative Wetting and Drying Test Results}

The test carried is as per the following, arbitrarily chosen blocks are six and they are dried.12 cycles of substitute moistening and evaporating is done. Declination in quality is noticed after this process.

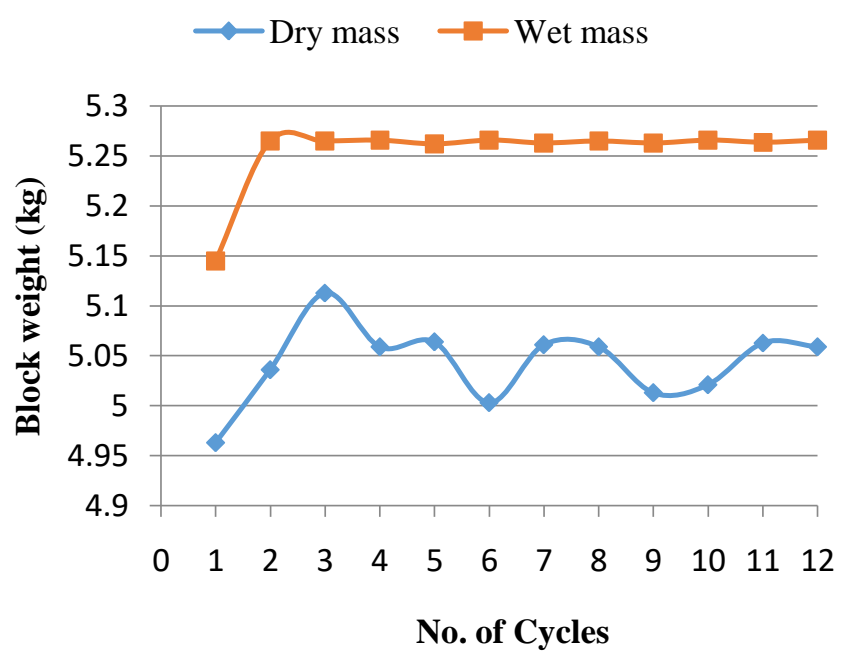

Fig 10: Average Mass of Blocks

C4B4 blocks are used. The normal mass of dry blocks shifts for every cycle because of the fluctuations in drying because of changing climate conditions. Extremly minor changes is seen as the blocks can't ingest water beyond immersion point.

WCS and DCS marginally declined after 12 cycles of substitute wetting and drying. $12.79 \%$ and $4.85 \%$ loss in WCS and DCS is watched separately. No visual harm is noticed.

Table 4: \% Loss in Strength

\begin{tabular}{|l|l|l|l|}
\hline $\begin{array}{l}\text { Paramete } \\
\text { rs }\end{array}$ & $\begin{array}{l}\text { Actual } \\
\text { Compressive } \\
\text { Strength(N/m } \\
\left.\mathbf{m}^{\mathbf{2}}\right)\end{array}$ & $\begin{array}{l}\text { Compressiv } \\
\text { e Strength } \\
\text { after 12 } \\
\text { cycles(N/m } \\
\left.\mathbf{m}^{\mathbf{2}}\right)\end{array}$ & $\begin{array}{l}\text { \% Loss } \\
\text { in } \\
\text { Strengt } \\
\mathbf{h}\end{array}$ \\
\hline WCS & 3.703 & 3.283 & 12.79 \\
\hline DCS & 6.152 & 5.867 & 4.85 \\
\hline
\end{tabular}

WCS and DCS marginally declined after 12 cycles of substitute moistening and evaporation. $12.79 \%$ and $4.85 \%$ loss in WCS and DCS is watched separately. No visual harm is noticed. 


\subsection{Expansion on Saturation Test Results}

Clay content in the block will responsible for contraction on drying and expansion on wetting of blocks. Saturated blocks are dried to constant mass.

The dimensions of dry and saturated blocks (48 hours immersed in water) are measured using vernier scale

Table 5: Expansion on Saturation Results

\begin{tabular}{|c|c|c|c|c|}
\hline $\begin{array}{l}\text { Sl. } \\
\text { No } \\
\text { (B) }\end{array}$ & Parameters & $\begin{array}{l}\mathbf{I M}^{*} \\
(\mathbf{m m})\end{array}$ & $\begin{array}{l}\text { FM } \\
(\mathbf{m m})\end{array}$ & $\begin{array}{l}\text { Expansion } \\
\text { in }(\%)\end{array}$ \\
\hline \multirow{3}{*}{ B1 } & $\mathbf{L}$ & 229.515 & 229.589 & 0.032 \\
\hline & $\mathbf{W}$ & 108.036 & 108.079 & 0.039 \\
\hline & $\mathbf{H}$ & 99.005 & 99.041 & 0.036 \\
\hline \multirow{3}{*}{ B2 } & $\mathbf{L}$ & 230.003 & 230.065 & 0.033 \\
\hline & $\mathbf{W}$ & 108.502 & 108.549 & 0.043 \\
\hline & $\mathbf{H}$ & 98.504 & 98.535 & 0.031 \\
\hline \multirow{3}{*}{ B3 } & $\mathbf{L}$ & 230.009 & 230.082 & 0.031 \\
\hline & $\mathbf{W}$ & 108.015 & 108.053 & 0.035 \\
\hline & $\mathbf{H}$ & 99.531 & 99.570 & 0.039 \\
\hline
\end{tabular}

IM Initial Measurement

FM Final Measurement

Expansion on immersion qualities ranges from $0.03 \%$ to $0.04 \%$. Most extreme admissible extension quality is $0.15 \%$. As the rate of extension is inside of the reasonable farthest point, the clay content in stabilized soil is admirable and the stabilization of bagasse ash blocks is found to be palatable.

\subsection{Masonry Prism Test}

\section{Compression Test}

The UTM is used for Compression test of balanced out mud square masonary. The uniaxial compression load is acting on the center of the prism. At last demec gage is unfixed well before the failure of the prism. Loading of prisms is carried out until the failure of prisms occurs.

\section{Flexural Strength}

The bond in the middle of block and mortar is vital in a wall for a few reasons. At the point when the two are all around fortified the wall shows great auxiliary uprightness and carries on like one unit. Once more, bond gets to be critical when a wall is exposed to parallel loads because of wind or seismic tremors.

Table 6: Test results of prism for C4B4 block

\begin{tabular}{|l|l|}
\hline Parameters & $\begin{array}{l}\text { Obtained } \\
\text { values }\end{array}$ \\
\hline $\begin{array}{l}\text { Height to Thickness } \\
\text { ratio }(\mathrm{h} / \mathrm{t})\end{array}$ & 4 \\
\hline Correction Factor & 1.3 \\
\hline $\begin{array}{l}\text { Corrected Prism } \\
\text { Strength }\end{array}$ & $1.85 \mathrm{~N} / \mathrm{mm}^{2}$ \\
\hline Masonary Efficiency & $49.95 \%$ \\
\hline Basic Compressive & $0.46 \mathrm{~N} / \mathrm{mm}^{2}$ \\
\hline
\end{tabular}

\begin{tabular}{|l|l|}
\hline Strength & \\
\hline Flexural strength & $0.26 \mathrm{~N} / \mathrm{mm}^{2}$ \\
\hline
\end{tabular}

Correction factor is found out for the height to thickness ratio using Table 12 of IS 1905 - 1987. In compression prisms failed by developing vertical split cracks and in flexure the prism failed by failure of bond or brick. All values obtained are satisfactory.

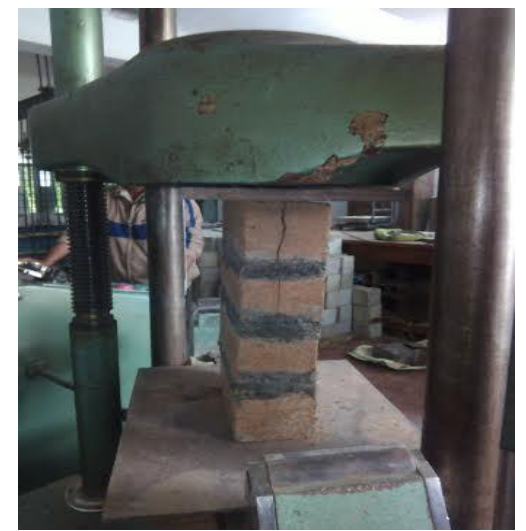

Fig 11: Failure Pattern of Masonry Prism in Compression

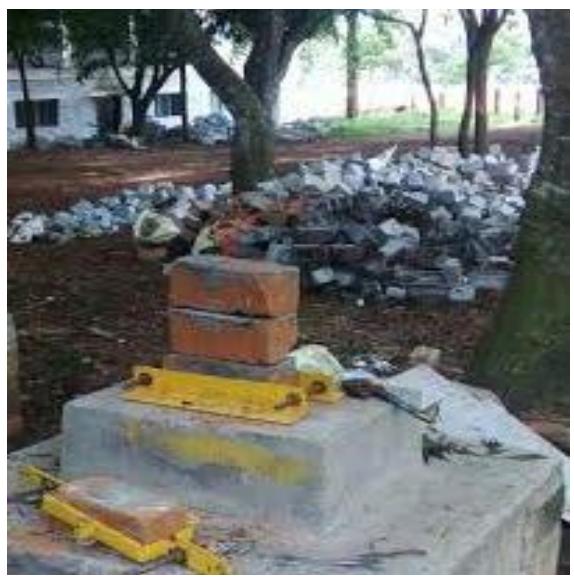

Fig 12: Failure Pattern of Masonry Prism in Flexure

\section{CONCLUSION}

1) Bagasse ash can be utilized as a additional stabilizing agent with cement as primary stabilizer.

2) For every rate substitution of cement by ash there is diminishing of block thickness and compressive quality, however the blocks will have a smoother finishing and well characterized corners.

3) Stabilized blocks with stabilizer mix C4B4 have a wet compressive quality and dry compressive quality of $3.703 \mathrm{~N} / \mathrm{mm}^{2}$ and $6.152 \mathrm{~N} / \mathrm{mm}^{2}$.The blocks of this stabilizer blend fulfills every one of the particulars of Class 30 evaluation of SMB as given in IS 17251982.In this type of blocks cement quantity reduces because half of the cement is replaced with baggase ash.

4) The water ingestion estimations of blocks are inside of the cut off values and diminish with increment in ash percentage. Bagasse ash goes about a filler material topping of pores.

5) This type of blocks results in cost reduction and are ecofriendly. 


\section{REFERENCES}

[1] Apurva Kulkarni, Samrudda Raje , Mamta Rajgor, "BAGGASE ASH AS AN EFFECTIVE REPLACEMENE IN FLYASH BRICKS", International Journal of Engineering Trends and Technology(IJETT) -Vol.4,Oct 2013

[2] B. V. Venkatarama Reddy and Ajay Gupta "STRENGTH AND ELASTIC PROPERTIES OF STABILIZED MUD BLOCK MASONRY USING CEMENT-SOIL MORTARS". Journal of Materials in Civil Engineering (C) ASCE / May/June 2006

[3] B.V.Venkatarama Reddy "SUSTAINABLE BUILDING TECHNOLOGIES". Current Science, Vol. 87, NO. 7, 10 October 2004

[4] Dr. R. Kumutha \& Dr. K. Vijay "FEASIBILITY STUDY ON UTILISATION OF LATERITE SOIL FOR STABILIZED EARTH BLOCK". Research Desk, 2013, Jul-Sep 2(3). 229-236

[5] Gaurav kumar P. Barot, "STUDY ON UTILIZATION OF WASTE MATERIAL FOR CONSTRUCTION BRICK", Journal of International Academic Research for Multidisciplinary, Vol.2 ,Issue 5, June 2014

[6] IS: 3495-1,1976. "METHODS OF TESTS OF BURNT CLAY BUILDING BRICKS: PART 1DETERMINATION OF COMPRESSIVE STRENGTH". Bureau of Indian Standards, New Delhi, India.

[7] IS: 1725, 1982. "SPECIFICATION FOR SOIL BASED BLOCKS USED IN GENERAL BUILDING CONSTRUCTION". Bureau of Indian Standards, New Delhi, India.

[8] IS 2720 - 1985 (Part 5): "METHODS OF TEST FOR SOILS, PART 5: DETERMINATION OF LIQUID AND PLASTIC LIMIT", Bureau of Indian Standards, New Delhi, India

[9] IS 2250 - 1981: "CODE OF PRACTICE FOR PREPARATION AND USE OF MASONRY MORTARS", Bureau of Indian Standards, New Delhi, India.

[10] IS 2212 - 1991: "CODE OF PRACTICE FOR BRICKWORKS", Bureau of Indian Standards, New Delhi, India.

[11] IS 1077 - 1992: "COMMON BURNT CLAY BUILDING BRICKS - SPECIFICATION", Bureau of Indian Standards, New Delhi, India.

[12] IS 1725 - 1982: "SPECIFICATION FOR SOIL BASED BLOCKS USED IN GENERAL BUILDING CONSTRUCTION", Bureau of Indian Standards, New Delhi, India.

[13] IS 3812 - 2003 (Part 1): "SPECIFICATION FOR PULVERIZED FUEL ASH, PART 1: FOR USE AS POZZOLANA", Bureau of Indian Standards, New Delhi, India.

[14] K.S. Jagadish, "ALTERNATIVE BUILDING MATERIALS AND TECHNOLOGY", New Age International, 01-Jan-2008

[15] Ken C. Onyelowe, CEMENT STABILIZED AKWUETE LATERITIC SOIL AND THE USE OF BAGGASE ASH AS ADMIXTURE,
International Journal of Science And Engineering Investigations, Vol.1,issue 2, March 2012

[16] Osinubi.K.J and Alhassan.M: BAGASSE ASH MODIFICATION OF SHIKA LATERITE, Nigerian Journal of Engineering, 2007, Vol 14, No Pp9674104

[17] Payá .J, Monzó,.J , Borrachero .M V, Díaz-Pinzón .L, Ordóñez .L M: SUGAR-CANE BAGASSE ASH (SCBA): STUDIES ON ITS PROPERTIES FOR REUSING IN CONCRETE PRODUCTION, Journal of Chemical Technology \& Biotechnology, 2007, Volume 77 Issue 3, pp. $21-32$.

[18] Rafael Alavez -Raimez, Pedro Montes-Garcia, etal, THE USE OF SUGARCANE BAGGASE ASH AND LIME TO IMPROVE THE DURABILITY AND MECHANICAL PROPERTIES OF COMPACTED SOIL BLOCKS , Construction and Building Material by Science Direct-2012

[19] Ramadhan W.Salim, Julius M.Ndambuki and David Adedokun, IMPROVING THE BEARING STRENGTH OF SANDY LOAM SOIL COMPRESSED EARTH BLOCK USING SUGARCANE BAGGASE ASH, International Journal of Sustainability, 10 June 2014.

[20] S. Deboucha, and R. Hashim, "A REVIEW ON BRICKS AND STABILIZED COMPRESSED EARTH BLOCKS," Scientific Research and Essays, vol. 6 (3), pp. 499-506, 2011

[21] Sales A, Lima SA. USE OF BRAZILIAN SUGARCANE BAGASSE ASH IN CONCRETE AS SAND REPLACEMENT. Waste Manage (Oxford) 2010;30:1114-22.

[22] Tabin Rushad, Abhishek Kumar .S.,Duggal S.K., Mehta P.K,(2011), "EXPERIMENTAL STUDIES ON LIME SOIL FLY ASH BRICKS”, International Journal of Civil and Structural Engineering, 1(4),904-1002

[23] Venkatarama Reddy B.V, Prasanna Kumar P, (2011), "CEMENT STABILIZED RAMMED EARTH. COMPRESSIVE STRENGTH AND STRESSSTRAIN CHARACTERISTICS", Materials and Structures, 44, 695-707 